\title{
Can Community Managed Grasslands Help Maintain Globally Threatened Bird Populations?
}

\author{
- Hem Sagar Baral*
}

Broadly speaking Nepal has three major habitat types; namely forests, wetlands and grasslands (Baral and Inskipp 2004). The term 'grassland' has been used as a broad term for carpeted ground with short grasses or towering heights of elephant grass. The tall grasslands of northern India and southern Nepal have been considered to be the most threatened of the habitat types in the region (Grimmett et al. 1998). The height of some grass species in lowland Nepal reach $8 \mathrm{~m}$ or even more, making it perhaps the tallest grassland regions of the world!

Grasslands support high biodiversity, a higher number of globally threatened animal taxa are found here compared to other habitats in Nepal. Nepal grasslands are internationally important for conservation of many fauna as they harbor significant portion of many grassland birds' population. Sadly due to the widespread habitat loss and over-exploitation of the natural resources, the grasslands are shrinking day by day (Peet et al. 1999).

Tall elephant grasslands in southern Nepal are home to many species of threatened fauna (Baral 2001). These include Nepal's charismatic large mammals and other megafauna such as One-horned Rhinoceros Rhinoceros unicornis, Bengal Tiger Panthera tigris, Gaur Bos gaurus, Wild Buffalo Bubalus arnee, Asian Elephant Elephas maximus and Sloth Bear Melursus ursinus and five species of deer. Many of these mammals have been studied (Laurie 1982, Mishra 1982, Smith 1984, Dinerstein 1987), however work on avifauna of grasslands started only from the 1990s. Almost 20 species of globally threatened animals are believed to be heavily dependent on these grasslands. Baral (2001) listed 31 grassland birds as priority species for conservation, several of these now are globally threatened indicating urgency to act for them (BirdLife International 2006).

The importance of grassland as an important habitat for birds is documented (Baral 2001). Prior to the start of grassland bird conservation programme under the aegis of University of Amsterdam, only three grassland species were studied in Nepal: Bengal Florican Houbaropsis bengalensis (Inskipp and Inskipp 1983, Weaver 1991), Sarus Crane Grus antigone (Suwal 2002), Swamp Francolin Francolinus gularis (Baral 1998). Since the onset of the grassland bird conservation programme a number of research work has been carried out on the ecology of the threatened grassland avifauna. These include, Bengal Florican (Chaudhary 2002, Baral et al. 2000 and 2002), Swamp Francolin (Dahal 2002, Singh 2007), Hodgson's Bushchat Saxicola insignis (Baral 1998), Sarus Crane (Suwal 2002), Lesser Adjutant Leptoptilos javanicus (Hundgen and Clarkson 2003, Tamang 2003, Gyawali 2003, Chaudhary 2007), Grey-crowned Prinia (Baral 2002) and Slender-billed Babbler (Baral 2006) etc. In addition to these birds, lowland grasslands are home to many little known species, eg White-tailed Stonechat Saxicola leucura, Rufous-rumped Grassbird Graminicola bengalensis, Pale-footed Bush-warbler Cettia pallidipes (Baral 2003, 2006, in press). Nepal grasslands also act as a limit for the world distribution of some grassland birds (Baral 2000).

Grass is also a vital resource for local people and now almost all such habitat is restricted to the protected areas (Sharma and Shaw 1993). Chitwan National Park, Sukla Phanta Wildlife Reserve, Bardia National Park and Koshi Tappu Wildlife Reserve are important grassland reserves (Peet et al. 1999). It is estimated that nearly $500 \mathrm{~km}^{2}$ is covered with tall grasslands, roughly $23 \%$ of the total $2230 \mathrm{~km}^{2}$ of vegetation cover in lowland protected areas (Baral 2001).

Grasses are the most used daily resource by the rural people. It is used to feed livestock and forms their staple diet. It is also used for various household uses; building houses, hats, mats, fishing baskets, tables, chairs etc. In recent years, a high demand of grasses has been put by the paper industry. Grass is highly renewable and fast growing resource used by all level of people but more by the ultra-poor people. This shows strong

Chief Executive Officer, Bird Conservation Nepal, PO Box $\overline{12} \overline{4} 6 \overline{5}, \bar{K}$ Kathmandu

062

The Initiation 2007 
connection of grassland habitat with humans living at the lowest level of economic standard. It is said that grass is used by humankind when a baby is first born and also during the funerals!

Loss of grasslands by deterioration, disturbance and natural succession are major issues for grassland conservation. Lack of new riverine areas for formation of new grasslands also poses serious threat. Threats to the grasslands has yet to be addressed as it is important habitat for several globally threatened species.

Grassland conservation in lowland Nepal has drawn attention in recent years. In the past conservation was taken in a rather narrow sense and conservation for many meant tree plantation (Baral 2001). International Trust for Nature Conservation (ITNC) have conducted grassland management experiment in small scale to promote habitat for Bengal Florican (Dhan Bahadur Chaudhary verbally 2005). The result of the latter study is not known.

As the grassland habitat itself is dependent on the dynamic regimes of floods, fire and disturbance, management of the habitat needs careful considerations. Present day management practice is mainly focused on large mammals. Management should be sympathetic also to birds, small mammals and other lesser fauna. Prescribed grassland management practiced in the protected areas need to be reviewed to see the changes on the composition of flora and fauna.

Conservation of grassland will help maintain grassland bio-diversity. This will increase sustainable use for various purposes. Sustainable management of the existing state-owned pasturelands and creation of new ones as community grasslands should be promoted. In addition to this local people and land owners should be encouraged for having their own private grasslands. To fulfill the human need rotational cattle grazing should be allowed in a way that promotes grass species diversity. Conservation education programmes run by CBOs and NGOs should promote grasslands in community forests and encourage to have community managed grasslands. Saccharum and Imperata grasslands are important for human beings and easily grown in the community managed lands. In fact these grasses are the first to grow in a fallow land, so additional input from us is minimum. Promotion of Themeda and Narenga grasslands (Peet et al. 1999) in the community managed grasslands should help promote conservation of threatened species. Community managed grasslands alone may not conserve all grassland birds but certainly will help several species to maintain their population at low risk.

\section{References}

Baral, H. S. (in press). Pale-footed Bush-warbler Cettia pallidipes in Nepal. Tigerpaper.

Baral, H. S. 2000. Notes on distribution of some grassland birds in Nepal with reference to Sukila Phanta. Danphe 9(3): 6-7.

Baral, H. S. 2001. Community structure and habitat associations of lowland grassland birds in Nepal. University of Amsterdam, Amsterdam.

Baral, H. S. 2002. Status, distribution and ecology of Grey-crowned Prinia Prinia cinereocapilla with new data from Nepal. Danphe 11(1): 21-24.

Baral, H. S. and Chaudhary, D. B. 2006. Status and distribution of Slender-billed Babbler Turdoides longirostris in Chitwan National Park, central Nepal. Danphe 15(4): 1-6.

Baral, H. S. and Inskipp, C. 2004. The state of Nepal's birds 2004. IUCN, DNPWC and BCN, Kathmandu.

Baral, H. S., Wattel, J., Brewin, P. and Ormerod, S. J. 2006. Status, distribution, ecology and behaviour of Rufous-rumped Grass-warbler Graminicola bengalensis Jerdon with reference to Nepal. Journal of Bombay Natural History Society 103 (1): 44-48.

Baral, N., Tamang, B. and Timilsina, N. 2000. The floricans in Royal Bardia National Park. Danphe 9(3): 4.

Baral, N., Timilsina, N. and Tamang, B. 2002. Conservationists peep into floricans. Danphe 11(1): 18-19.

BirdLife International 2006. Threatened birds of the world. www.birdlife.org

Brown, K. 1997. Plain tales from the grasslands: extraction, value and utilisation of biomass 
in Royal Bardia National Park, Nepal. Biodiversity and Conservation 6:59-74. Chaudhary, B. 2007. Nesting of Lesser Adjutant in Urlabari. Danphe 16(1): 70. Chaudhary, D. B. 2002. The Bengal Florican Houbaropsis bengalensis. Danphe 11(1): 1617.

Dahal, B. R. 2002. Swamp Francolin Francolinus gularis: its future at Koshi. Danphe 11(3): 3-4.

Dinerstein, E. 1987. Deer, plant phenology, and succession in the lowland forests of Nepal. Biology and Management of the Cervidae. Washington DC, Smithsonian Press Pp. 272-288.

Grimmett, R., Inskipp, C. and Inskipp, T. 1998. Birds of the Indian subcontinent. Christopher Helm, London.

Gyanwali, N. 2003. Population and habitat preferences of Lesser Adjutant Leptoptilos javanicus in Royal Chitwan National Park, central Nepal. Danphe 12(3/4): 8.

Hundgen, K. and Clarkson, C. 2003. Field observations on the Lesser Adjutant Leptoptilos javanicus at Chitwan. Danphe 12(3/4): 7-8.

Inskipp, C. and Inskipp, T. P. 1983. Results of a preliminary survey of Bengal Floricans Houbaropsis bengalensis in Nepal and India, 1982. International Council for Bird Preservation, Study Report No. 2, Cambridge.

Laurie, A. 1983. Behavioural ecology of the Greater one-horned rhinoceros Rhinoceros unicornis. Journal of Zoology 196: 307-341.

Mishra, H. R. 1982. The ecology and behaviour of chital Axis axis, in the Royal Chitwan National Park, Nepal. PhD dissertation, University of Edinburgh.

Peet, N., Watkinson, A. J., Bell, D. J. and Kattel, B. J. 1999. Plant diversity in the threatened sub-tropical grasslands of Nepal. Biological Conservation 88: 193-206.

Sharma, U. R. and Shaw, W. W. 1993. Role of Nepal's Royal Chitwan National Park in meeting the grazing and fodder needs of local people. Environmental Conservation 20(2): 139-142.

Singh, P. B. 2007. Status of Swamp Francolin Francolinus gularis in Suklaphanta Wildlife Reserve. Danphe 16(1) 68-69.

Smith, J. L. D. 1984. Dispersal, communication, and conservation strategies for the tiger Panthera tigris in Royal Chitwan National Park, Nepal. PhD dissertation, University of Minnesota, Minneapolis.

Suwal, R. 2002. Standing tall with Sarus Cranes. Danphe 11(1):15-16.

Tamang, K. R. 2003. Notes on the breeding of Lesser Adjutant Leptoptilos javanicus in Chitwan. Danphe 12(3/4): 9.

Weaver, D. J. 1991. A survey of Bengal Floricans Houbaropsis bengalensis at Royal Sukla Phanta Wildlife Reserve and Royal Bardia National Park, western Nepal, 1990. A report the Oriental Bird Club, UK.

ge

\begin{tabular}{|c|c|c|}
\hline विजयाढशमी तथा & विजयाढशमी तथा & विजयाढशमी तथा \\
\hline शुभ-ढ़िपावर्ली र०६४ & शुभ-ढ़िपावली र०६४ & शुभ-ढ़िपावली २०६४ \\
\hline को हार्दिक नंगलमय & को हार्दिक नंगलमय & को हार्दिक नंगलमय \\
\hline $\begin{array}{l}\text { शुभकामना व्यक्त } \\
\text { गर्छछों । }\end{array}$ & $\begin{array}{l}\text { शुभकामना व्यत्त } \\
\text { गर्छछों । }\end{array}$ & $\begin{array}{l}\text { शुभकामना व्यत्त } \\
\text { गर्छछछों । }\end{array}$ \\
\hline $\begin{array}{l}\text { शिवपुरी राष्ट्टिय निकुज्ज } \\
\text { काठमाण्डौ }\end{array}$ & $\begin{array}{l}\text { रारा राष्ट्रिय निकुज्ज } \\
\text { मगग }\end{array}$ & $\begin{array}{l}\text { मकालु वरुण राष्ट्रिय निकुज्ज } \\
\text { संखवासभा }\end{array}$ \\
\hline
\end{tabular}

